\title{
The Percy Sladen Expedition to Lake Titicaca, South America
}

\author{
By Prof. J. Stanley Gardiner, F.R.S.
}

$\Delta \mathrm{T}$ the International Geographical Congress held at Cambridge in 1928, Mr. Hope-Jones and Major Vallenas, representing the Sociedad Geografica de Lima, suggested that a British and the Trustees of the British Museum. The expedition is also receiving a generous welcome from the Peruvian and Bolivian Governments.

Lake Titicaca is situated in an area in the middle

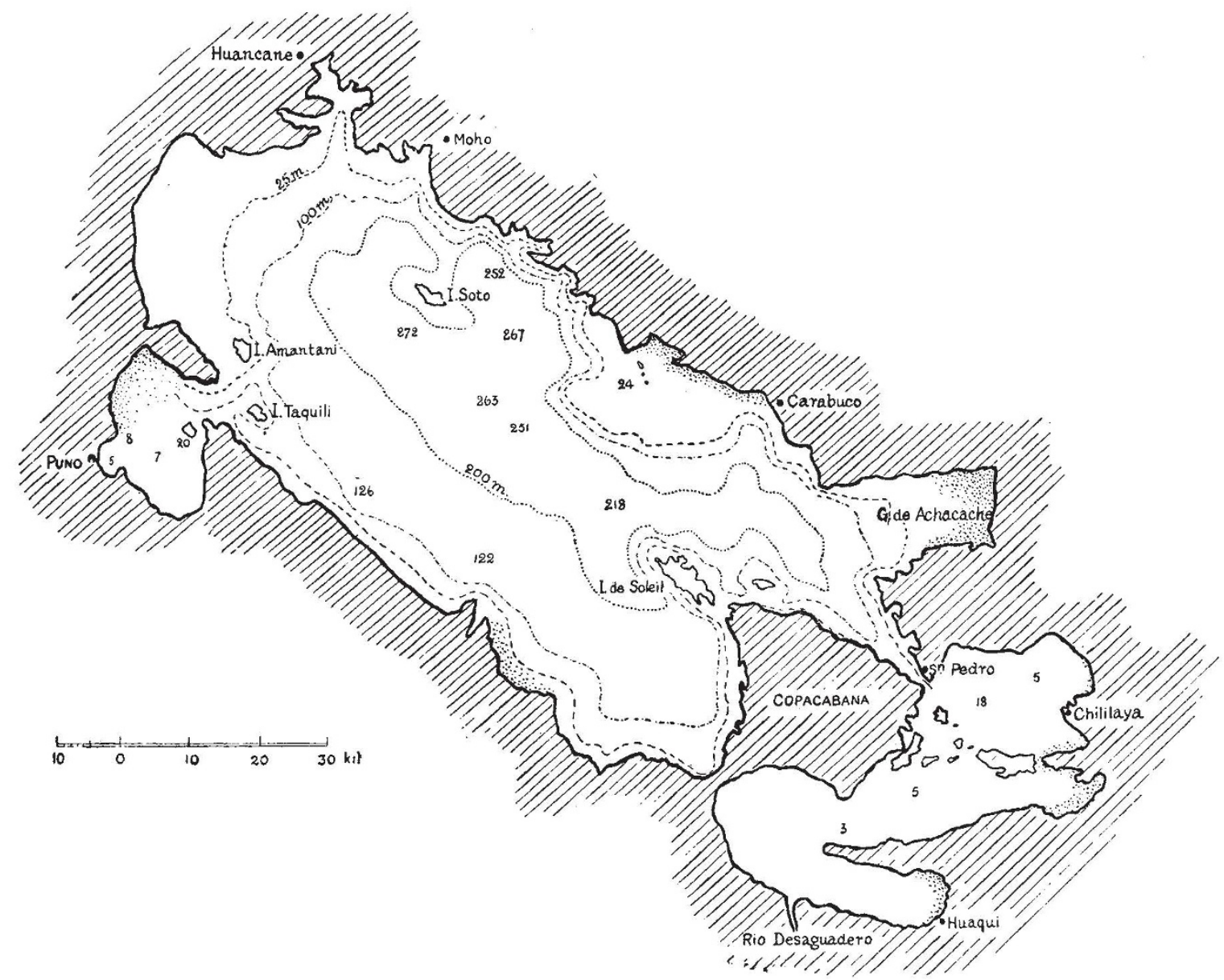

Fig. 1.

Lake Titicaca.

expedition be arranged for the investigation of Lake Titicaca in all its aspects, and proffered the support of their Society. Owing to financial conditions in Great Britain, the contemplation of such an expedition was not possible then or for some years. Finally, in January 1936, the matter was referred to the Percy Sladen Trustees, who decided to send an expedition to work on the lake during the winter or dry season (April-October) of the present year, the proposed researches meeting with the complete approval of the Royal Society of the Andes, where these mountains branch and afterwards rejoin, and about two thirds of the lake are in Peru and a third in Bolivia. It is situated at $12,500 \mathrm{ft}$. above sea-level and covers more than 3,000 square miles, its deepest sounding at present being 273 metres. It is fed mainly by streams from the mountains, which attain a height of $22,000 \mathrm{ft}$. to the east, while the railway pass from Molliendo to the west is at $14,666 \mathrm{ft}$., the total area of this central plain being more than 100,000 square miles. The lake itself is subject to differences in 
level of its waters, the causes of which are not clear, since it has an outflow by the Rio Desaguadero to the shallow Lake Poopo, about 300 miles to the south. Around this is a large area of partially overgrown marsh, into which there is extensive seepage from Poopo, the whole plain having no communication on any side with the sea. On Lake Titicaca the nights are cool, often with ground frost, but the days frequently experience a temperature range of $60^{\circ}-70^{\circ} \mathrm{F}$. How ever, the temperature of the lake remains relatively constant, perhaps due to the strong winds along its length from south to north causing mixation of its waters.

The country around, almost certainly the original home from which potatoes were imported into Europe, is for the most part dry and bare of timber. It is approached by the Southern Railway of Peru, the main line of which extends north to the Cuzco region, the central part of the Inca Empire. Around it are lead and other mines, and the Peruvian Corporation, which has most generously extended its help to the Expedition, besides managing the railway and conducting business enterprises, runs a regular steamer service from Puno in Peru, a town of more than 20,000 inhabitants, to Huaqui in Bolivia. Around the lake are a few small settlements, and the Island of the Sun in the Bolivian area is the centre of an important pilgrimage.

The lake itself is evidently little affected by drainage from settlements, and agriculture in its surrounding lands is little developed. It indeed seems to be fed mainly by glacier streams of relatively constant volume and composition. It was visited by Alexander Agassiz sixty years ago, when a few amphibians, two genera of fish and some higher crustaceans were obtained. Its birds were collected by an expedition from the American Museum, and lately there has been an investigation of its biology with the view of introducing more profitable fish, as has been done into some northern Peruvian lakes. Apart from the fauna and flora, the full range of which will have to be ascertained, the lake presents a unique field for ecological study. Its position suggests that it is a relatively primitive lake, and it may well belong to an 'oligotrophic' type, in contrast to the 'eutrophic' lakes of the East Indies and Central Africa. In this connexion, the question of its nitrogen cycle will be a main object of interest, the distribution of nitrates, nitrites, ammonia and organic nitrogen, the seasonal changes in the same at various depths to determine their transformations; such researches, perhaps owing to a certain simplicity in the lake, should form invaluable data for comparison with the more complicated phenomena of the sea. Simultaneous determinations will have to be made of the quantity, composition and distribution of the plankton, which is as yet unknown. To obtain an understanding here will necessitate $p \mathrm{H}$, oxygen, phosphate and other analyses. Further, the fauna and flora of the shallow waters of its long coast-line will have to be surveyed adequately and ecologically.

On the physical side, here is a lake with the sealevel pressure reduced to two thirds with consequent effects on wind-force. The solar radiation is greatly increased, especially at the ultra-violet end of the spectrum, which has particular biological significance. Here are two matters of which relatively little is known, and on which it is hoped that results may be obtained that will elucidate conditions in low-lying lakes. Measurements of light penetration are desirable to determine the limits in depth to which the phytoplankton can flourish. These are special subjects in the general hydrogxaphical study of the lake and of its circulation as revealed by temperature and density observations.

The expedition as now arranged is under the leadership of H. C. Gilson, fellow of Trinity College, Cambridge, who will be accompanied by T. G. Tutin as botanist, H. P. Moon, G. I. Crawford of the British Museum, P. F. Holmes and D. M. Hall. All are graduates of the University of Cambridge, relatively young, because at these altitudes no others can, without long acclimatization, be expected to carry on the constant labour that the expedition will entail, and because to the optimism of such must be assigned the scientific attack in new directions, for which they have now been preparing for many months. They are to be joined by Dr. H. E. Hinton as a volunteer, his study being the water-living insects of the lake and streams.

The expedition leaves England on March 11, Messrs. Gilson and Hinton having proceeded in advance on February 18 to present their credentials to the Peruvian Government and to arrange for camp and commissariat on the lake, on which it is hoped to obtain six months' continuous observation. Besides the necessary scientific equipment, the expedition is taking out a motor-launch especially equipped for its daily observations, its speed of 16 knots at sea-level reduced to about 10 knots at this altitude. While the whole of the members of the expedition in respect to its objects are to a large degree interchangeable, it is anticipated that they will fall into pairs concerned with the chemical, physical and shallow water ecological observations, the plankton, fauna and flora being the concern of all. Clearly, this expedition will not be a 'joy-ride', and it is one to which the good wishes of all the scientific world will be gladly extended. 